\title{
REVIEW
}

\section{Bench-to-bedside review: The gut as an endocrine organ in the critically ill}

\author{
Adam Deane ${ }^{1,2,3 *}$, Marianne J Chapman ${ }^{1,2,3}$, Robert JL Frase ${ }^{3,4,5}$ and Michael Horowitz $z^{3,5}$
}

\begin{abstract}
In health, hormones secreted from the gastrointestinal tract have an important role in regulating gastrointestinal motility, glucose metabolism and immune function. Recent studies in the critically ill have established that the secretion of a number of these hormones is abnormal, which probably contributes to disordered gastrointestinal and metabolic function. Furthermore, manipulation of endogenous secretion, physiological replacement and supra-physiological treatment (pharmacological dosing) of these hormones are likely to be novel therapeutic targets in this group. Fasting ghrelin concentrations are reduced in the early phase of critical illness, and exogenous ghrelin is a potential therapy that could be used to accelerate gastric emptying and/or stimulate appetite. Motilin agonists, such as erythromycin, are effective gastrokinetic drugs in the critically ill. Cholecystokinin and peptide YY concentrations are elevated in both the fasting and postprandial states, and are likely to contribute to slow gastric emptying. Accordingly, there is a rationale for the therapeutic use of their antagonists. So-called incretin therapies (glucagon-like peptide-1 and glucose-dependent insulinotropic polypeptide) warrant evaluation in the management of hyperglycaemia in the critically ill. Exogenous glucagon-like peptide-2 (or its analogues) may be a potential therapy because of its intestinotropic properties.
\end{abstract}

\section{Introduction}

In health, peptides released from the stomach and/or intestine modulate motility, secretion, absorption, mucosal growth and immune function of the gastrointestinal tract [1]. These hormones also have effects outside the gastrointestinal tract, particularly in relation

*Correspondence: Adam.Deane@adelaide.edu.au

'Royal Adelaide Hospital, Department of Intensive Care, North Terrace, Adelaide, 5000 South Australia

Full list of author information is available at the end of the article to the regulation of energy intake and glycaemia [1]. In critically ill patients, both the prevalence and magnitude of disordered gastrointestinal and metabolic function are substantial [2]. Moreover, many of these abnormalities are associated with poor outcomes [3]. It is now apparent that a number of gastrointestinal hormones mediate, or have the potential to mediate, some of the functional abnormalities that occur in the critically ill, either via increased or decreased secretion. The present review focuses on the abnormalities in gastrointestinal function and glucose metabolism that occur in the critically ill, focuses on current understanding of the effects of gastrointestinal hormones in health and critical illness, and focuses on implications of the above for management and priorities for future research.

\section{Gastrointestinal motility in critical illness}

Abnormalities in gastrointestinal motor function have recently been described, and quantified, in the critically ill using a number of measurement techniques not previously utilised in this cohort. Published studies are likely to have underestimated the prevalence and magnitude of these motor abnormalities, however, as - in our experience - patients with the most marked motor abnormalities are often the most technically demanding to study.

In the critically ill, motility of the entire gastrointestinal tract may be affected. In an observational study at our centre, the tone of the lower oesophageal sphincter was markedly reduced in all 15 critically ill patients studied and is likely to increase the propensity for gastro-oesophageal reflux [4]. In patients that are sedated and ventilated, reflux is regarded as a major cause of aspiration, and consequent ventilator-associated pneumonia [4].

Feed intolerance occurs in up to $50 \%$ of critically ill patients, predominately due to delayed gastric emptying, and is considered a risk factor for adverse sequelae, such as inadequate nutrition $[3,5]$. The motor function of the both the proximal and/or distal stomach is disordered in $\sim 50 \%$ of critically ill patients and underlies the delayed gastric emptying (which may also contribute to a higher frequency, and volume, of gastro-oesophageal reflux events) [6]. In health, the proximal stomach acts as a reservoir for liquid feed. In critical illness, however, the 


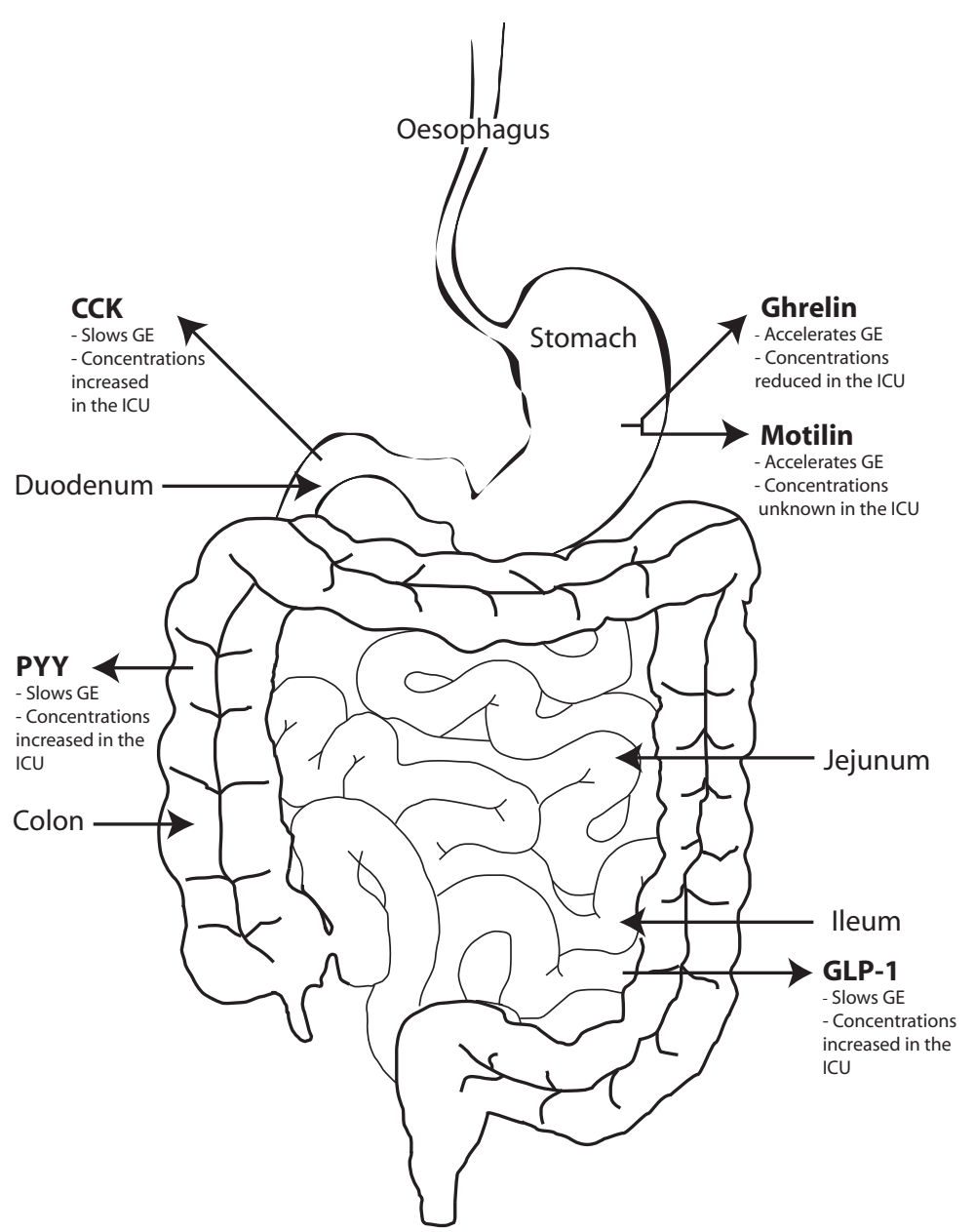

Figure 1. Hormones affecting gastric emptying in health and critical illness. Effect of hormones on gastric emptying (GE) in health and their known fasting concentrations in the critically ill. CCK, cholecystokinin; GLP, glucagon-like peptide; ICU, intensive care unit; PYY, peptide YY.

usual relaxation that occurs in response to the presence of nutrient is delayed and reduced [7]. The coordination, magnitude and frequency of contractions in the proximal and distal stomach are reduced, leading to decreased transpyloric flow of chyme $[7,8]$. The interaction of nutrient with small-intestinal receptors (mediated, at least in part, via enterogastric hormones) is pivotal to the regulation of gastric emptying in health and critical illness. However, in the critically ill inhibitory smallintestinal feedback on gastric emptying appears to be substantially enhanced (Figure 1) [6].

The effects of critical illness on small-intestinal motility are poorly defined, although disorganisation of duodenal pressure waves occurs frequently, with increased retrograde activity and diminished propagation of antegrade pressure waves [9]. It is likely that some patients have slow small-intestinal transit, due to prolonged periods of quiescent motor activity, and that a proportion of patients, as a result of disordered burst-like motor activity, have subsequent rapid transit. This concept is supported by a study from Rauch and colleagues in which non-nutrient small-intestinal transit times in 16 neurointensive care patients (admitted $<4$ days) were measured using video capsule technology. They reported that median transit times were similar, albeit with greater inter-subject variability, to those in health [10]. The effect of critical illness on colonic motility is yet to be evaluated.

\section{Gastrointestinal absorptive and immune function in the critically ill}

Absorption of nutrient is substantially impaired in the critically ill (Figure 2 ) $[11,12]$. The altered absorption may be a consequence of disordered transit of chyme and/or impaired mucosal function [12]. In addition, the epithelial barrier function is impaired, with a consequent increase in gastrointestinal permeability, and a potential predisposition to translocation of enteric organisms, systemic infection and, hence, adverse outcomes [11,13]. 


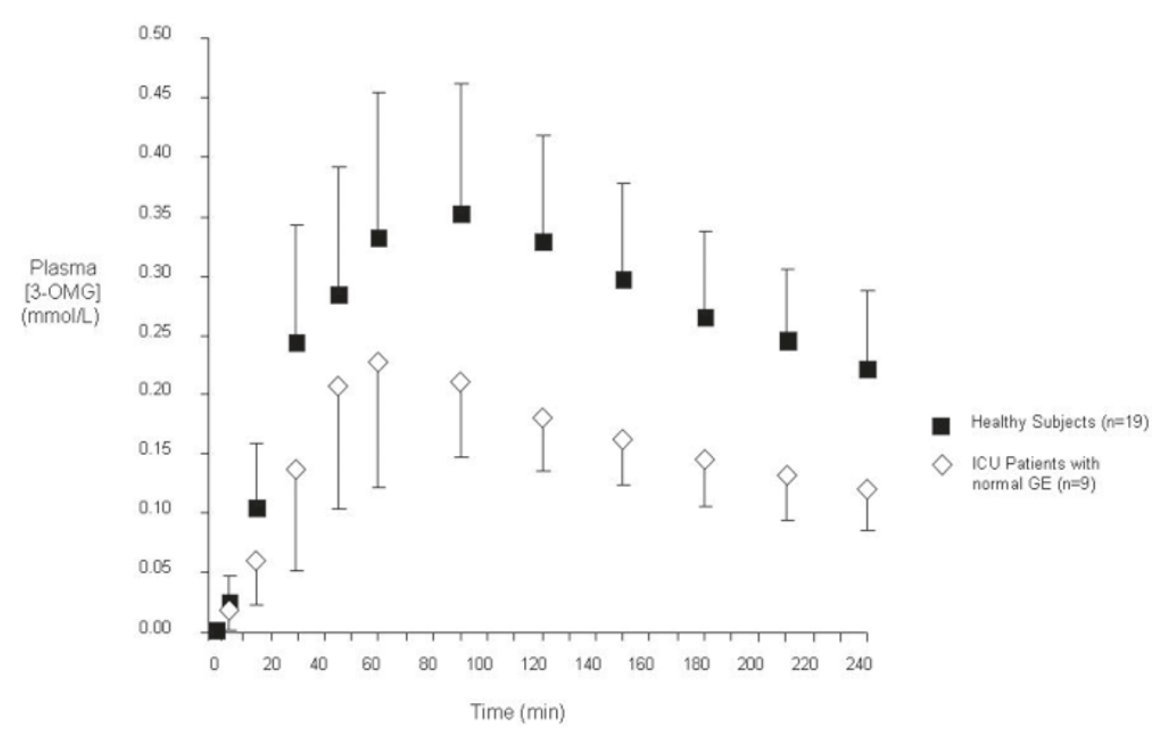

Figure 2. Absorption of carbohydrate is impaired in the critically ill. In nine critically ill patients (with normal gastric emptying (GE)) both peak and area under the curve (AUC) concentrations for plasma 3-O-methyl-glucose [3-OMG] (an index of glucose absorption) were markedly attenuated when compared with 19 healthy subjects. [3-OMG] AUC $_{0-240 \text { min }}$ : critically ill patients, $38.9 \pm 11.4 \mathrm{mmol} / \mathrm{l} / \mathrm{min}$ vs. healthy subjects, $66.6 \pm 16.8 \mathrm{mmol} / \mathrm{I} / \mathrm{min} ; P<0.001$ (mean \pm standard deviation). Reproduced from [12]. ICU, intensive care unit.

\section{Glucose metabolism in the critically ill}

Hyperglycaemia is common in acute illness, even in those patients without pre-existing diabetes [14]. The Leuven trial established that marked hyperglycaemia (blood glucose $>12 \mathrm{mmol} / \mathrm{l}$ ) is associated with poor outcomes in surgical intensive care unit patients [15]. This landmark study resulted in a paradigm shift in the management of glycaemia in the critically ill. Subsequent studies, however, reported that substantial hypoglycaemia (blood glucose $<2.2 \mathrm{mmol} / \mathrm{l}$ ) occurred frequently with intensive insulin therapy, and hypoglycaemia is also associated with adverse outcomes [16]. Hence, while the optimum blood glucose target in the critically ill remains uncertain [17], treatment of hyperglycaemia and avoidance of iatrogenic hypoglycaemia are priorities. Moreover, there is evidence that glycaemic variability, in addition to mean glucose, is deleterious [18]. Safer methods for the management of hyperglycaemia in the critically ill are therefore desirable.

\section{Methods}

We performed a comprehensive search, restricted to manuscripts written in English, on MEDLINE/PubMed, from inception to 1 July 2009. We used both the following $\mathrm{MeSH}$ terms and combinations of these terms: gastrointestinal hormones, ghrelin, motilin, cholecystokinin, peptide YY, glucagon-like peptide-1, glucagon-like peptide-2, glucose-dependent insulinotropic polypeptide, incretins, critical illness, intensive care. In addition, we searched the bibliographies of retrieved articles manually.

\section{Results and discussion}

The gastrointestinal hormones most likely to be of clinical significance are reviewed. For each hormone, a summary of where the peptide is stored, stimuli for secretion and the location of receptors is provided. Studies relating to the potential physiological effects focus on the use of the specific antagonists. In addition, physiological replacement and pharmacological dosing studies are presented when relevant.

\section{Ghrelin}

Ghrelin is a 28 -amino-acid peptide secreted primarily from the stomach during fasting [19]. Secretion is suppressed by meal ingestion, chiefly as a result of the interaction of nutrients with the small intestine [20]. The magnitude of this suppression appears to be dependent on the length of small intestine exposed to nutrient [21], but not the energy load [22]. Fasting plasma ghrelin concentrations are inversely related to body weight, with relatively lower concentrations in obesity and higher concentrations in anorectic patients [23]. Receptors to ghrelin are distributed widely, including the hypothalamus, pituitary and stomach [24].

Studies using exogenous ghrelin (infused to replicate physiological fasting concentrations) indicate that ghrelin is an important acute stimulant of appetite [19]. Furthermore, treatment with an oral ghrelin mimetic for 2 years has been reported to increase fat-free body mass in older humans [25]. Exogenous ghrelin at supra-physiological concentrations accelerates gastric emptying in humans 
and in animal models of sepsis-induced gastroparesis [26-28]. The ghrelin agonist, TZP-101, accelerates emptying substantially in patients with gastroparesis [29]. TZP-101 has also been reported to reduce the postoperative ileus time in animals [30], and this may also be the case in humans (Dr G Kostuic, personal communication). Pharmacological doses of ghrelin also increase fasting blood glucose and suppress plasma insulin secretion [31].

Fasting plasma ghrelin concentrations are markedly reduced $(>50 \%)$ in the early phase of critical illness, with suppression continuing up to day 28 post admission [32]. The reduction in ghrelin secretion may play a role in delayed gastric emptying, weight loss and decreased appetite that all occur frequently in the critically ill. The same investigators reported that there was an exaggerated suppression of plasma ghrelin in response to nutrient in patients post cardiac surgery (day 6), when compared with preoperative concentrations, or in healthy controls, and suggested this may contribute to early satiation in postoperative patients [33]. The suppression of ghrelin (that is, change from fasting concentration), however, was apparent because of elevated fasting levels. While the increase in fasting concentrations in postoperative patients appears inconsistent with the findings in critical illness, it is likely that 6 days after elective surgery, albeit major surgery, is not representative of the more profound changes in physiology that occur during critical illness.

Ghrelin (either physiological replacement or pharmacological doses) has not been evaluated as a therapy in critically ill patients. Exogenous ghrelin has, however, been reported to improve outcomes in patients with chronic organ failure. In open-label studies by Nagaya and colleagues, ghrelin was given for 3 weeks to patients with chronic lung disease or cardiac failure - with a consequent modest increase in exercise tolerance apparent with the intervention in both studies [34,35]. The underlying mechanism(s) is likely to be via both growth hormone effects (skeletal muscle strength) and growth hormone-independent effects (appetite).

\section{Motilin}

Motilin is structurally related to ghrelin, and motilin receptors are located throughout the gastrointestinal tract [36]. Motilin secretion is stimulated during the interdigestive state, and the peak plasma motilin concentration coincides with the onset of frequent gastrointestinal antegrade contractions (that is, phase III of the migrating motor complex) [37]. Exogenous motilin induces antegrade contractions in the stomach and, consequently, accelerates gastric emptying in health and gastroparesis [38].

Because oral formulations allow easier administration in outpatients, nonpeptide motilin agonists (motilides) have been developed as prokinetic agents, rather than motilin itself. Erythromycin has the capacity to accelerate gastric emptying profoundly in both healthy individuals and ambulant patients with gastroparesis [39,40]. The effect is attenuated by hyperglycaemia [41], however, and the response may not be sustained as a result of tachyphylaxis [42]. Motlilides have also been reported to increase lower oesophageal sphincter pressure [43] and to affect small-intestinal motility, such that intravenous erythromycin at doses $\sim 3 \mathrm{mg} / \mathrm{kg}$ has been reported to slow small-intestinal transit $[44,45]$.

The effect of critical illness on plasma concentrations of motilin is not known. Despite this, the gastrokinetic effects of motilides make them a suitable drug to improve feed tolerance in the critically ill [6]. While acceleration of gastric emptying may not improve fasting, or mealrelated, symptoms in ambulatory patients with gastroparesis, acceleration of the gastric emptying rate and, thereby, improving enteral feed tolerance is the primary outcome of relevance in the sedated critically ill patient, rather than symptom relief [6]. Accordingly, erythromycin has been shown to be a potent gastrokinetic in the critically ill $[46,47]$, although in $\sim 60 \%$ of patients its effects are diminished within 7 days [46].

\section{Cholecystokinin}

Cholecystokinin (CCK) is stored in enteroendocrine cells in the duodenum and jejunum, and is secreted in response to the presence of fat, protein and, to a lesser degree, carbohydrate in the small intestine [48]. The use of specific antagonists, such as loxiglumide, has afforded a greater understanding of the physiological actions of CCK on luminal motility, secretory function and appetite. Appetite and energy intake are increased during loxiglumide infusion [49]. In the postprandial phase, CCK may reduce the lower oesophageal sphincter basal pressure and increase the frequency of transient lower oesophageal sphincter relaxations, with a consequent increase in the number of gastro-oesophageal reflux events [50]. Endogenous CCK also slows gastric emptying in humans and may accelerate small-intestinal transit $[51,52]$. CCK is the principle physiological regulator of gallbladder contraction and augments pancreatic protein enzyme secretion, with both effects suppressed by loxiglumide [53].

In critically ill patients, fasting plasma CCK concentrations are approximately twice those of healthy controls, and nutrient-stimulated CCK concentrations are some 1.5-fold greater [54]. Furthermore, fasting plasma CCK concentrations are higher in critically ill patients with delayed gastric emptying, when compared with those with normal emptying (Figure 3) [55]. The reduction in appetite (and gastric emptying) that occurs in healthy ageing has been attributed, in part, to increased concentrations and/ 
(a)

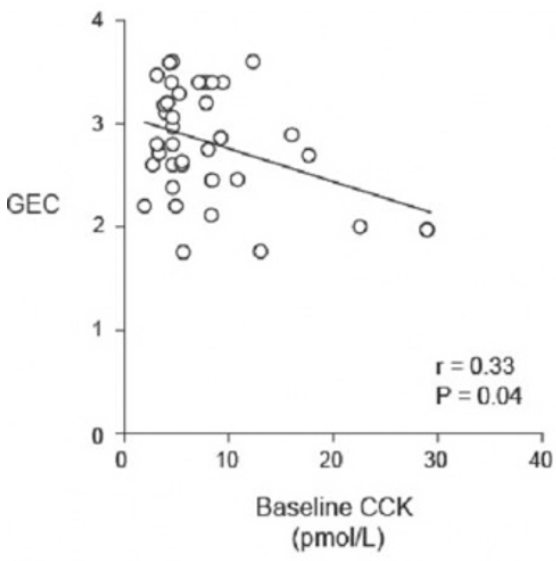

(b)

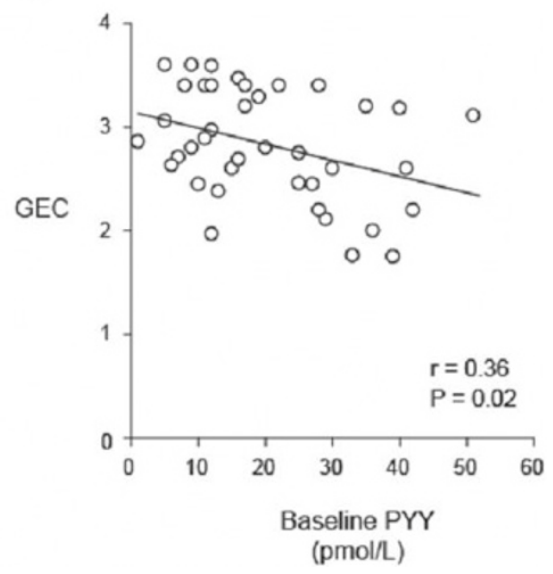

Figure 3. Relationship between rate of gastric emptying and fasting cholecystokinin and peptide YY concentrations. Relationship between the rate of gastric emptying (measured using an isotope breath test and calculated as the gastric emptying coefficient (GEC); greater number, more rapid emptying) and (a) fasting cholecystokinin (CCK) concentrations ( $r=-0.33 ; P=0.04)$ and (b) fasting peptide $Y Y(P Y Y)$ concentrations $(r=-0.36$; $P=0.02$ ) in 39 critically ill patients. Reproduced with permission from [55].

or sensitivity to CCK [56]. Likewise, CCK may have the same satiety effect in the critically ill, and CCK may be a mediator of slow gastric emptying in this group. Studies involving administration of a CCK antagonist are required to evaluate this hypothesis.

The mechanism(s) underlying exaggerated CCK response is also unknown. Prolonged nutrient deprivation in patients with anorexia nervosa is associated with an increase in plasma CCK [57]. Accordingly, we anticipated that early, rather than delayed, enteral nutrition in the critically ill may attenuate CCK secretion and improve feed tolerance. A shorter ( $<1$ day) period neither blunted an increase in CCK concentration or accelerated gastric emptying, however, when compared with a longer (4 day) period of nutrient deprivation in critically ill patients [58].

\section{Peptide YY}

Peptide YY (PYY) is secreted predominantly from the colon and rectum, and, to a lesser extent, from the pancreas, distal small intestine and stomach [59]. Fat is the most potent stimulant of PYY secretion $[59,60]$. Plasma PYY concentrations increase within 15 minutes of a meal [60], suggesting that an indirect neural or hormonal response is responsible for initial stimulation, with peak concentrations occurring at $\sim 1$ hour [60]. CCK may mediate the initial PYY secretion, with subsequent direct intraluminal stimulation causing sustained PYY secretion [60]. Pharmacological doses of PYY slow gastric emptying and small-intestinal transit [61], and endogenous PYY is likely to modulate gastric emptying in health. Exogenous PYY also inhibits appetite, and these anorectic effects have encouraged the investigation of PYY as a weight-loss therapy [62].

In an observational study of seven critically ill patients, Nematy and colleagues reported that fasting PYY concentrations were increased approximately threefold in the acute phase of critical illness, when compared with health [32]. Moreover, we reported that fasting plasma PYY concentrations in 39 critically ill patients were increased substantially in those that had delayed gastric emptying (Figure 3) [55]. Our group has also shown that the PYY response to small-intestinal nutrient infusion is exaggerated in the critically ill when compared with health [54]. Animal models of sepsis suggest that PYY concentrations increase rapidly following systemic infection [63]. Like CCK, endogenous PYY secretion is increased; and if receptor sensitivity remains unchanged, both hormones are candidate mediators to slow gastric emptying in the critically ill. PYY concentrations have been shown to progressively normalise as the clinical condition improves.

\section{Glucagon-like peptide-1}

The so-called incretin effect refers to the greater insulinotropic response to an oral glucose load, as compared with an isoglycaemic intravenous infusion [64]. Glucagon-like peptide (GLP)-1 is one of the two known incretin hormones, and is secreted from intestinal $\mathrm{L}$ cells (which are located primarily in the distal ileum and colon) in response to luminal fat, carbohydrate and protein [65]. Studies using the specific GLP-1 antagonist, exendin (9-39) amide, have established that endogenous GLP-1 lowers fasting glycaemia and attenuates postprandial glycaemic 


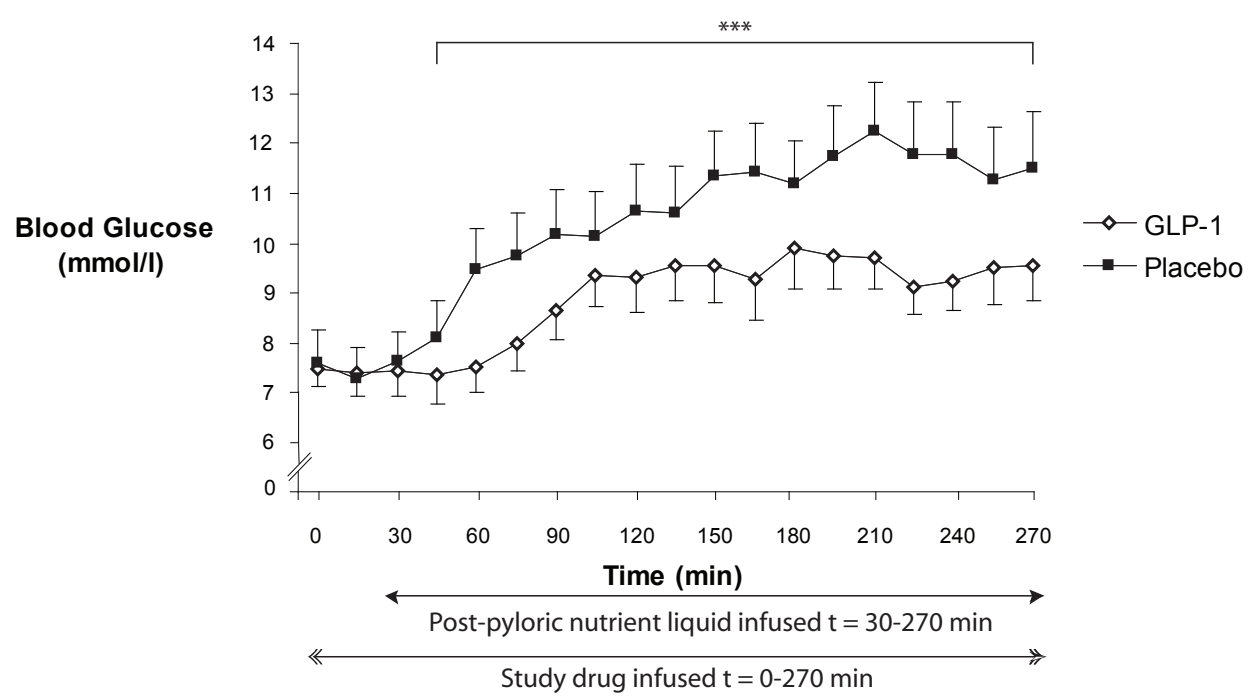

Figure 4. The effect of glucagon-like peptide-1 on glycaemia in critically ill patients. In a cross-over study, exogenous glucagon-like peptide (GLP)-1 (1.2 pmol/kg/min) markedly attenuated the overall glycaemic response to intraduodenal nutrient infusion. Area under the curve ${ }_{30-270 \mathrm{~min}}$ GLP-1, 2,077 $\pm 144 \mathrm{mmol} / \mathrm{l} / \mathrm{min}$ vs. placebo, $2,568 \pm 208 \mathrm{mmol} / \mathrm{l} / \mathrm{min} ; n=7 ; * * * P<0.05$. Reproduced from [81].

excursions [66,67]. The glucose-lowering reflects slower gastric emptying, as well as increased insulin and decreased glucagon secretion [66-68].

Pharmacological doses of GLP-1 reduce both fasting and postprandial glycaemia [69,70]. Importantly, the effects of exogenous GLP-1 to stimulate insulin and suppress glucagon are glucose dependent, and thus the risk of hypoglycaemia is not increased substantially, even with pharmacological dosing [71]. Furthermore GLP-1 in pharmacological doses appears to slow gastric emptying, which contributes substantially to the glucose-lowering effect [72]. Animal and human studies suggest that exogenous GLP-1 inhibits fasting jejunal motility [73,74], which is anticipated to slow small-intestinal transit. There are significant extra-gastrointestinal and islet cell effects of exogenous GLP-1, with the potential cardioprotective effects of specific interest to the critically ill cohort $[75,76]$.

In non-intensive care unit inpatients receiving total parenteral nutrition, Nauck and colleagues established that pharmacological doses of GLP-1 have the capacity to lower glycaemia [77]. Subsequently, Meier and colleagues reported that in type 2 diabetic patients after major surgery an acute infusion of GLP-1 reduces fasting glucose [78]. Recently, GLP-1 has also been reported to lower perioperative glycaemia in cardiac surgical patients $[79,80]$. Given its inherent safety profile yet substantial effects on gastrointestinal motility, we studied the effects of exogenous GLP-1 (1.2 pmol/ $/ \mathrm{kg} / \mathrm{min})$ in nondiabetic critically ill patients, and established that GLP-1 markedly attenuates the glycaemic response to smallintestinal nutrition (Figure 4) [81]. In critically ill patients, however, enteral nutrient is delivered predominantly via the intragastric route and marked slowing of gastric emptying may be undesirable. Accordingly, we evaluated the effects of exogenous GLP-1 on gastric emptying of an intragastric meal [82]. While an acute infusion of GLP-1 $(1.2 \mathrm{pmol} / \mathrm{kg} / \mathrm{min})$ slowed gastric emptying when the latter was relatively normal (and to thereby contribute to glucose lowering), no effect was evident when emptying was already delayed [82].

\section{Glucose-dependent insulinotropic peptide}

The other known incretin hormone is glucose-dependent insulinotropic peptide (GIP) - which is secreted from duodenal K cells [83], primarily in response to luminal fat and carbohydrate [84]. GIP is markedly insulinotropic, but in contrast to GLP-1, it has no enterogastrone effect (that is, it has no effect on either gastric acid secretion or gastric emptying). In addition, GIP is glucagonotropic during euglycaemia, and has a substantially diminished insulinotropic effect in type 2 diabetic patients [85].

Small-intestinal nutrient is recognised to stimulate GIP secretion in the critically ill [86], but the magnitude of GIP response when compared to secretion in healthy subjects has not been evaluated. Likewise the pharmacological effects of GIP in the critically ill are unknown.

\section{Glucagon-like peptide-2}

GLP-2 is co-secreted (with GLP-1) from L cells in response to luminal nutrient [87]. GLP-2 receptors are morphologically similar to the other proglucagon products (GLP-1, GIP) and are present in the stomach, small bowel, colon, lung and brain [88]. 
Exogenous GLP-2 has no effect on gastric emptying [88]. Furthermore, in contrast to GLP-1, the peptide is glucagonotropic and has no effect on insulin secretion [89]. Despite the islet cell effects, postprandial glycaemia is unaffected by exogenous GLP-2 [89]. Animal models have consistently demonstrated that GLP-2 in pharmacological doses potently stimulates intestinal growth, enhances absorptive function and improves mesenteric blood flow, thereby protecting the intestinal mucosa from injury $[90,91]$. There have been preliminary reports of beneficial effects using both GLP-2, and its analogue, teduglutide, in patients with short-bowel syndrome $[92,93]$. The physiological concentrations and/or effects of pharmacological infusions of GLP-2 remain to be studied in the critically ill.

\section{Clinical implications and future research directions}

Further studies of the physiological effects of these hormones in the critically ill are indicated. It would be desirable to determine the basal and nutrient-stimulated concentrations of motilin, as well as the proglucagon products (that is, GLP-1, GIP and GLP-2) in this group. In addition, an improved understanding of the mechanism(s) of increased or decreased hormone concentrations in this heterogeneous group would be of benefit.

Given the association between the rate of gastric emptying with hormone (CCK and PYY) concentrations, the use of specific antagonists is appealing in certain circumstances; for example, the CCK antagonist, loxiglumide, is a novel therapy that may prove to be a useful prokinetic in the critically ill. A potential concern is that CCK antagonists may also modify pancreatic exocrine function and, thereby, nutrient absorption. Accordingly, the absorption of nutrient should be assessed in studies of CCK antagonist use. A specific group of critically ill patients who warrant study using one of these agents is those with severe acute pancreatitis. CCK analogues have the capacity to induce acute pancreatitis in humans [94]. Furthermore, studies of treatment with CCK antagonists in animal models of pancreatitis as well as in patients with chronic pancreatitis have reported benefits $[94,95]$.

Studies of the effects of physiological replacement, or pharmacological doses, of several of these hormones may also be worthwhile. Exogenous ghrelin, and/or its analogues, are potential therapies to accelerate gastric emptying in patients with delayed gastric emptying and ileus, and/or to stimulate appetite after prolonged critical illness. The use of ghrelin also has the potential to cause adverse effects in the critically ill, however, because ghrelin is the ligand for the growth hormone secretagogue receptor. While critical illness is associated with suppressed growth hormone secretion, trials with supra-physiological growth hormone replacement have reported adverse outcomes [96]. Despite the adverse effects reported in studies of pharmacological growth hormone, careful evaluation of the effects of short-term (7 to 21 days) treatment with ghrelin, or an analogue, to establish the effects on gastric emptying and/or appetite in the critically ill is indicated. The motilin receptor also represents a target for therapy in the critically ill. Concerns of erythromycin-associated adverse events, including the potential to induce antibiotic resistance, have limited the general use of motilides for feed intolerance [97]. Accordingly, there is a need to assess the efficacy of nonantibiotic motilides - which have shown some promise in accelerating gastric emptying in healthy individuals and ambulant patients [6].

Incretin-based therapies are likely to find a place in the management of hyperglycaemia in the intensive care unit, whether associated with type 2 diabetes or stressinduced diabetes. As discussed, a potential advantage is that pharmacological GLP-1 does not appear to increase the risk of hypoglycaemia substantially [71] and, as such, the peptide may be infused on a continuous basis without the necessity to titrate the dose [98]. In addition, affecting both insulin and glucagon may attenuate the variability in glycaemia when using GLP-1 compared with insulin therapy. To date we have evaluated the effects of the synthetic peptide to establish proof of concept. It should be recognised that the peptide is, currently, prohibitively expensive for routine clinical use. There may well be a substantial reduction in cost of the peptide, however, should a market become available.

Alternatively, GLP-1 analogues (resistant to dipeptylpeptidase-4 degradation) that are currently available for management of glycaemia in ambulant patients with type 2 diabetes may prove useful. While more affordable, these agents (such as exenatide and liraglutide) have potential disadvantages, including unpredictable plasma concentrations in the critically ill, as well as antibody formation, which require evaluation [99]. Further to evaluating the effects of the individual proglucagon products (that is, GLP-1, GLP-2 and GIP), the use of dipeptyl-peptidase-4 inhibition to increase endogenous concentrations of all three peptides also merits evaluation. As described, profound effects on gastric emptying and/or small-bowel transit are almost certainly undesirable, and the effects of exogenous GLP-1 on the gastrointestinal tract during prolonged administration in the critically ill should be examined. The potential for an increased risk of gastroesophageal reflux, and consequent aspiration, and the effects on nutrient delivery and absorption represent priorities for future studies.

GIP is probably the dominant incretin in health, does not slow gastric emptying and has the potential to cause weight gain [85]. Accordingly, GIP may have a more desirable profile than GLP-1. However, the insulinotropic 
effect of GIP is markedly attenuated in type 2 diabetics as well as $\sim 50 \%$ of their first-degree relatives [100]. The reduction in insulinotropic effect is due, at least in part, to the effects of hyperglycaemia. Whether a proportion of patients with stress-induced hyperglycaemia will likewise be nonresponsive to GIP pharmacotherapy, thereby limiting its use to specific patients, remains to be determined.

GLP-2 has potential as a therapy to stimulate intestinal growth and improve nutrient absorption in the critically ill. Furthermore, GLP-2 may reduce secondary infections in the critically ill, given that GLP-2 decreased translocation of bacteria in a rat model of acute necrotising pancreatitis [101]. While previous therapies targeting luminal immune modulation have been successful in animal studies but unsuccessful in human critical illness trials [102], GLP-2 warrants evaluation as a potential therapy in specific subgroups of patients.

\section{Conclusions}

The secretion of a number of gastrointestinal hormones is disordered in the critically ill, and may mediate abnormalities in luminal motility and, potentially, changes in absorption, metabolism and immunity in this group. Treating disordered hormone secretion (with manipulation of endogenous secretion, specific antagonists, exogenous infusion of hormones, or their analogues) represents a novel therapeutic approach that warrants evaluation, and has the potential to lead to improved outcomes in critically ill patients.

\section{Abbreviations \\ CCK, cholecystokinin; GIP, glucose-dependent insulinotropic peptide; GLP, glucagon-like peptide; PYY, peptide YY.}

\section{Competing interests}

The authors declare that they have no competing interests.

\section{Author details}

'Royal Adelaide Hospital, Department of Intensive Care, North Terrace, Adelaide 5000, South Australia. ${ }^{2}$ University of Adelaide, Discipline of Acute Care Medicine, North Terrace, Adelaide 5000, South Australia. ${ }^{3}$ National Health and Medical Research Council Centre for Clinical Research Excellence in Nutritional Physiology, Interventions and Outcomes, Level 6, Eleanor Harrald Building, Frome St, Adelaide 5000, South Australia. ${ }^{4}$ Investigation and Procedures Unit, Repatriation General Hospital, Daws Road, Daw Park 5041, South Australia. ${ }^{5}$ University of Adelaide, Discipline of Medicine, North Terrace, Adelaide 5000, Australia.

\section{Published: 24 September 2010}

\section{References}

1. Baynes KC, Dhillo WS, Bloom SR: Regulation of food intake by gastrointestinal hormones. Curr Opin Gastroenterol 2006, 22:626-631.

2. Thompson JS: The intestinal response to critical illness. Am J Gastroenterol 1995, 90:190-200.

3. Nguyen NQ, Ng MP, Chapman M, Fraser RJ, Holloway RH: The impact of admission diagnosis on gastric emptying in critically ill patients. Crit Care 2007, 11:R16

4. Nind G, Chen WH, Protheroe R, Iwakiri K, Fraser R, Young R, Chapman M, Nguyen N, Sifrim D, Rigda R, Holloway RH: Mechanisms of gastroesophageal reflux in critically ill mechanically ventilated patients. Gastroenterology 2005, 128:600-606.

5. Heyland DK, Tougas G, King D, Cook DJ: Impaired gastric emptying in mechanically ventilated, critically ill patients. Intensive Care Med 1996, 22:1339-1344.

6. Deane AM, Fraser RJ, Chapman MJ: Prokinetic drugs for feed intolerance in critical illness: current and potential therapies. Crit Care Resusc 2009, 11:132-143.

7. Nguyen NQ, Fraser RJ, Chapman M, Bryant LK, Holloway RH, Vozzo R, FeinleBisset C: Proximal gastric response to small intestinal nutrients is abnormal in mechanically ventilated critically ill patients. World J Gastroenterol 2006, 12:4383-4388.

8. Chapman M, Fraser R, Vozzo R, Bryant L, Tam W, Nguyen N, Zacharakis B, Butler R, Davidson G, Horowitz M: Antro-pyloro-duodenal motor responses to gastric and duodenal nutrient in critically ill patients. Gut 2005, 54:1384-1390.

9. Chapman MJ, Fraser RJ, Bryant LK, Vozzo R, Nguyen NQ, Tam W, Zacharakis B, Davidson G, Butler R, Horowitz M: Gastric emptying and the organization of antro-duodenal pressures in the critically ill. Neurogastroenterol Motil 2008, 20:27-35.

10. Rauch S, Krueger K, Turan A, Roewer N, Sessler DI: Determining small intestinal transit time and pathomorphology in critically ill patients using video capsule technology. Intensive Care Med 2009, 35:1054-1059.

11. Johnston JD, Harvey CJ, Menzies IS, Treacher DF: Gastrointestinal permeability and absorptive capacity in sepsis. Crit Care Med 1996, 24:1144-1149.

12. Chapman MJ, Fraser RJ, Matthews G, Russo A, Bellon M, Besanko LK, Jones KL, Butler R, Chatterton B, Horowitz M: Glucose absorption and gastric emptying in critical illness. Crit Care 2009, 13:R140.

13. Wiest R, Rath HC: Gastrointestinal disorders of the critically ill. Bacterial translocation in the gut. Best Pract Res Clin Gastroentero/ 2003, 17:397-425.

14. Whitcomb BW, Pradhan EK, Pittas AG, Roghmann MC, Perencevich EN: Impact of admission hyperglycemia on hospital mortality in various intensive care unit populations. Crit Care Med 2005, 33:2772-2777.

15. van den Berghe $G$, Wouters P, Weekers F, Verwaest C, Bruyninckx F, Schetz M, Vlasselaers D, Ferdinande P, Lauwers P, Bouillon R: Intensive insulin therapy in the critically ill patients. N Engl J Med 2001, 345:1359-1367.

16. Van den Berghe G, Wilmer A, Hermans G, Meersseman W, Wouters PJ, Milants I, Van Wijngaerden E, Bobbaers H, Bouillon R: Intensive insulin therapy in the medical ICU. N Engl J Med 2006, 354:449-461.

17. Finfer S, Chittock DR, Su SY, Blair D, Foster D, Dhingra V, Bellomo R, Cook D, Dodek P, Henderson WR, Hébert PC, Heritier S, Heyland DK, McArthur C, McDonald E, Mitchell I, Myburgh JA, Norton R, Potter J, Robinson BG, Ronco JJ: Intensive versus conventional glucose control in critically ill patients. $N$ Engl J Med 2009, 360:1283-1297.

18. Egi M, Bellomo R, Stachowski E, French CJ, Hart G: Variability of blood glucose concentration and short-term mortality in critically ill patients. Anesthesiology 2006, 105:244-252.

19. Wren AM, Seal $\amalg$, Cohen MA, Brynes AE, Frost GS, Murphy KG, Dhillo WS, Ghatei MA, Bloom SR: Ghrelin enhances appetite and increases food intake in humans. J Clin Endocrinol Metab 2001, 86:5992-5995.

20. Parker BA, Doran S, Wishart J, Horowitz M, Chapman IM: Effects of small intestinal and gastric glucose administration on the suppression of plasma ghrelin concentrations in healthy older men and women. Clin Endocrinol (Oxf) 2005, 62:539-546.

21. Little TJ, Doran S, Meyer JH, Smout AJ, O'Donovan DG, Wu KL, Jones KL, Wishart J, Rayner CK, Horowitz M, Feinle-Bisset C: The release of GLP-1 and ghrelin, but not GIP and CCK, by glucose is dependent upon the length of small intestine exposed. Am J Physiol 2006, 291:E647-E655.

22. Cukier K, Pilichiewicz AN, Chaikomin R, Brennan IM, Wishart JM, Rayner CK, Jones KL, Horowitz M, Feinle-Bisset C: Effect of small intestinal glucose load on plasma ghrelin in healthy men. Am J Physiol Regul Integr Comp Physiol 2008, 295:R459-R462.

23. Misra M, Miller KK, Herzog DB, Ramaswamy K, Aggarwal A, Almazan C, Neubauer G, Breu J, Klibanski A: Growth hormone and ghrelin responses to an oral glucose load in adolescent girls with anorexia nervosa and controls. J Clin Endocrinol Metab 2004, 89:1605-1612.

24. Davenport AP, Bonner TI, Foord SM, Harmar AJ, Neubig RR, Pin JP, Spedding M, Kojima M, Kangawa K: International Union of Pharmacology. LVI. Ghrelin receptor nomenclature, distribution, and function. Pharmacol Rev 2005, 57:541-546. 
25. Nass R, Pezzoli SS, Oliveri MC, Patrie JT, Harrell FE, Jr, Clasey JL, Heymsfield SB, Bach MA, Vance ML, Thorner MO: Effects of an oral ghrelin mimetic on body composition and clinical outcomes in healthy older adults: a randomized trial. Ann Intern Med 2008, 149:601-611.

26. Tack J, Depoortere I, Bisschops R, Verbeke K, Janssens J, Peeters T: Influence of ghrelin on gastric emptying and meal-related symptoms in idiopathic gastroparesis. Aliment Pharmacol Ther 2005, 22:847-853.

27. Murray CD, Martin NM, Patterson M, Taylor SA, Ghatei MA, Kamm MA, Johnston C, Bloom SR, Emmanuel AV: Ghrelin enhances gastric emptying in diabetic gastroparesis: a double blind, placebo controlled, crossover study. Gut 2005, 54:1693-1698.

28. De Winter BY, De Man JG, Seerden TC, Depoortere I, Herman AG, Peeters TL, Pelckmans PA: Effect of ghrelin and growth hormone-releasing peptide 6 on septic ileus in mice. Neurogastroenterol Motil 2004, 16:439-446.

29. Ejskjaer N, Vestergaard ET, Hellstrom PM, Gormsen LC, Madsbad S, Madsen JL, Jensen TA, Pezzullo JC, Christiansen JS, Shaughnessy L, Kosutic G: Ghrelin receptor agonist (TZP-101) accelerates gastric emptying in adults with diabetes and symptomatic gastroparesis. Aliment Pharmacol Ther 2009, 29:1179-1187.

30. Venkova K, Fraser G, Hoveyda HR, Greenwood-Van Meerveld B: Prokinetic effects of a new ghrelin receptor agonist TZP-101 in a rat model of postoperative ileus. Dig Dis Sci 2007, 52:2241-2248.

31. Broglio F, Arvat E, Benso A, Gottero C, Muccioli G, Papotti M, van der Lely AJ, Deghenghi R, Ghigo E: Ghrelin, a natural GH secretagogue produced by the stomach, induces hyperglycemia and reduces insulin secretion in humans. $J$ Clin Endocrinol Metab 2001, 86:5083-5086.

32. Nematy M, O'Flynn JE, Wandrag L, Brynes AE, Brett SJ, Patterson M, Ghatei MA Bloom SR, Frost GS: Changes in appetite related gut hormones in intensive care unit patients: a pilot cohort study. Crit Care 2006, 10:R10.

33. Nematy M, Brynes AE, Hornick PI, Patterson M, Ghatei MA, Bloom SR, Brett SJ, Frost GS: Postprandial ghrelin suppression is exaggerated following major surgery; implications for nutritional recovery. Nutr Metab (Lond) 2007, 4:20.

34. Nagaya N, Itoh T, Murakami S, Oya H, Uematsu M, Miyatake K, Kangawa K: Treatment of cachexia with ghrelin in patients with COPD. Chest 2005, 128:1187-1193.

35. Nagaya N, Moriya J, Yasumura Y, Uematsu M, Ono F, Shimizu W, Ueno K, Kitakaze M, Miyatake K, Kangawa K: Effects of ghrelin administration on left ventricular function, exercise capacity, and muscle wasting in patients with chronic heart failure. Circulation 2004, 110:3674-3679.

36. Takeshita E, Matsuura B, Dong M, Miller LJ, Matsui H, Onji M: Molecular characterization and distribution of motilin family receptors in the human gastrointestinal tract. J Gastroenterol 2006, 41:223-230.

37. Vantrappen G, Janssens J, Peeters TL, Bloom SR, Christofides ND, Hellemans J: Motilin and the interdigestive migrating motor complex in man. Dig Dis Sci 1979, 24:497-500.

38. Peeters TL, Muls E, Janssens J, Urbain JL, Bex M, Van Cutsem E, Depoortere I, De Roo M, Vantrappen G, Bouillon R: Effect of motilin on gastric emptying in patients with diabetic gastroparesis. Gastroenterology 1992, 102:97-101.

39. Janssens J, Peeters TL, Vantrappen G, Tack J, Urbain JL, De Roo M, Muls E, Bouillon R: Improvement of gastric emptying in diabetic gastroparesis by erythromycin. Preliminary studies. N Engl J Med 1990, 322:1028-1031.

40. Fraser R, Shearer T, Fuller J, Horowitz M, Dent J: Intravenous erythromycin overcomes small intestinal feedback on antral, pyloric, and duodenal motility. Gastroenterology 1992, 103:114-119.

41. Jones KL, Berry M, Kong MF, Kwiatek MA, Samsom M, Horowitz M: Hyperglycemia attenuates the gastrokinetic effect of erythromycin and affects the perception of postprandial hunger in normal subjects. Diabetes Care 1999, 22:339-344

42. Thielemans L, Depoortere I, Perret J, Robberecht P, Liu Y, Thijs T, Carreras C, Burgeon E, Peeters TL: Desensitization of the human motilin receptor by motilides. J Pharmacol Exp Ther 2005, 313:1397-1405

43. Chaussade S, Michopoulos S, Sogni P, Guerre J, Couturier D: Motilin agonist erythromycin increases human lower esophageal sphincter pressure by stimulation of cholinergic nerves. Dig Dis Sci 1994, 39:381-384

44. Edelbroek MA, Horowitz M, Wishart JM, Akkermans LM: Effects of erythromycin on gastric emptying, alcohol absorption and small intestinal transit in normal subjects. J Nucl Med 1993, 34:582-588.

45. Landry C, Vidon N, Sogni P, Nepveux P, Chaumeil JC, Chauvin JP, Couturier D, Chaussade S: Effects of erythromycin on gastric emptying, duodeno-caecal transit time, gastric and biliopancreatic secretion during continuous gastric infusion of a liquid diet in healthy volunteers. Eur J Gastroenterol Hepatol
1995, 7:797-802.

46. Nguyen NQ, Chapman MJ, Fraser RJ, Bryant LK, Holloway RH: Erythromycin is more effective than metoclopramide in the treatment of feed intolerance in critical illness. Crit Care Med 2007, 35:483-489.

47. Maclaren R, Kiser TH, Fish DN, Wischmeyer PE: Erythromycin vs metoclopramide for facilitating gastric emptying and tolerance to intragastric nutrition in critically ill patients. J Parenter Enteral Nutr 2008, 32:412-419.

48. Pilichiewicz AN, Chaikomin R, Brennan IM, Wishart JM, Rayner CK, Jones KL Smout AJ, Horowitz M, Feinle-Bisset C: Load-dependent effects of duodenal glucose on glycemia, gastrointestinal hormones, antropyloroduodenal motility, and energy intake in healthy men. Am J Physiol 2007, 293:E743-E753.

49. Beglinger C, Degen L, Matzinger D, D'Amato M, Drewe J: Loxiglumide, a CCK-A receptor antagonist, stimulates calorie intake and hunger feelings in humans. Am J Physiol Regul Integr Comp Physiol 2001, 280:R1149-R1154.

50. Clave P, Gonzalez A, Moreno A, Lopez R, Farre A, Cusso X, D'Amato M, Azpiroz F, Lluis F: Endogenous cholecystokinin enhances postprandial gastroesophageal reflux in humans through extrasphincteric receptors. Gastroenterology 1998, 115:597-604

51. Fried M, Erlacher U, Schwizer W, Lochner $C$, Koerfer J, Beglinger $C$, Jansen JB, Lamers CB, Harder F, Bischof-Delaloye A, Stalder GA, Rovati L: Role of cholecystokinin in the regulation of gastric emptying and pancreatic enzyme secretion in humans. Studies with the cholecystokinin-receptor antagonist loxiglumide. Gastroenterology 1991, 101:503-511.

52. Schwizer W, Borovicka J, Kunz P, Fraser R, Kreiss C, D'Amato M, Crelier G, Boesiger $P$, Fried M: Role of cholecystokinin in the regulation of liquid gastric emptying and gastric motility in humans: studies with the CCK antagonist loxiglumide. Gut 1997, 41:500-504

53. Hildebrand P, Beglinger C, Gyr K, Jansen JB, Rovati LC, Zuercher M, Lamers CB, Setnikar I, Stalder GA: Effects of a cholecystokinin receptor antagonist on intestinal phase of pancreatic and biliary responses in man. J Clin Invest 1990, 85:640-646.

54. Nguyen NQ, Fraser RJ, Chapman MJ, Bryant LK, Holloway RH, Vozzo R, Wishart J Feinle-Bisset C, Horowitz M: Feed intolerance in critical illness is associated with increased basal and nutrient-stimulated plasma cholecystokinin concentrations. Crit Care Med 2007, 35:82-88.

55. Nguyen NQ, Fraser RJ, Bryant LK, Chapman MJ, Wishart J, Holloway RH, Butler R, Horowitz M: The relationship between gastric emptying, plasma cholecystokinin, and peptide YY in critically ill patients. Crit Care 2007, 11:R132

56. Maclntosh CG, Morley JE, Wishart J, Morris H, Jansen JB, Horowitz M, Chapman IM: Effect of exogenous cholecystokinin (CCK)-8 on food intake and plasma CCK, leptin, and insulin concentrations in older and young adults: evidence for increased CCK activity as a cause of the anorexia of aging. J Clin Endocrinol Metab 2001, 86:5830-5837.

57. Baranowska B, Radzikowska M, Wasilewska-Dziubinska E, Roguski K, Borowiec M: Disturbed release of gastrointestinal peptides in anorexia nervosa and in obesity. Diabetes Obes Metab 2000, 2:99-103.

58. Nguyen NQ, Fraser RJ, Bryant LK, Burgstad C, Chapman MJ, Bellon M, Wishart J, Holloway RH, Horowitz M: The impact of delaying enteral feeding on gastric emptying, plasma cholecystokinin, and peptide YY concentrations in critically ill patients. Crit Care Med 2008, 36:1469-1474.

59. Adrian TE, Ferri GL, Bacarese-Hamilton AJ, Fuessl HS, Polak JM, Bloom SR Human distribution and release of a putative new gut hormone, peptide YY. Gastroenterology 1985, 89:1070-1077.

60. Lin HC, Chey WY, Zhao X: Release of distal gut peptide YY (PYY) by fat in proximal gut depends on CCK. Peptides 2000, 21:1561-1563.

61. Savage AP, Adrian TE, Carolan G, Chatterjee VK, Bloom SR: Effects of peptide YY (PYY) on mouth to caecum intestinal transit time and on the rate of gastric emptying in healthy volunteers. Gut 1987, 28:166-170.

62. Batterham RL, Cohen MA, Ellis SM, Le Roux CW, Withers DJ, Frost GS, Ghatei MA, Bloom SR: Inhibition of food intake in obese subjects by peptide YY3-36. N Engl J Med 2003, 349:941-948.

63. Zamir O, Hasselgren PO, Higashiguchi T, Frederick JA, Fischer JE: Effect of sepsis or cytokine administration on release of gut peptides. Am J Surg 1992, 163:181-184; discussion 184-185

64. Perley MJ, Kipnis DM: Plasma insulin responses to oral and intravenous glucose: studies in normal and diabetic sujbjects. J Clin Invest 1967, 46:1954-1962.

65. Schirra J, Katschinski M, Weidmann C, Schafer T, Wank U, Arnold R, Goke B: Gastric emptying and release of incretin hormones after glucose ingestion in humans. J Clin Invest 1996, 97:92-103. 
66. Schirra J, Nicolaus M, Roggel R, Katschinski M, Storr M, Woerle HJ, Goke B: Endogenous glucagon-like peptide 1 controls endocrine pancreatic secretion and antro-pyloro-duodenal motility in humans. Gut 2006, 55:243-251.

67. Edwards CM, Todd JF, Mahmoudi M, Wang Z, Wang RM, Ghatei MA, Bloom SR: Glucagon-like peptide 1 has a physiological role in the control of postprandial glucose in humans: studies with the antagonist exendin 9-39. Diabetes 1999, 48:86-93

68. Deane AM, Nguyen NQ, Stevens JE, Fraser RJ, Holloway RH, Besanko LK, Burgstad C, Jones KL, Chapman MJ, Rayner CK, Horowitz M: Endogenous glucagon-like peptide-1 slows gastric emptying in healthy subjects, attenuating postprandial glycemia. J Clin Endocrinol Metab 2010, 95:215-221.

69. Kreymann B, Williams G, Ghatei MA, Bloom SR: Glucagon-like peptide-1 7-36: a physiological incretin in man. Lancet 1987, 2:1300-1304.

70. Nauck MA, Heimesaat MM, Orskov C, Holst JJ, Ebert R, Creutzfeldt W: Preserved incretin activity of glucagon-like peptide 1 [7-36 amide] but not of synthetic human gastric inhibitory polypeptide in patients with type-2 diabetes mellitus. J Clin Invest 1993, 91:301-307.

71. Nauck MA, Heimesaat MM, Behle K, Holst JJ, Nauck MS, Ritzel R, Hufner M, Schmiegel WH: Effects of glucagon-like peptide 1 on counterregulatory hormone responses, cognitive functions, and insulin secretion during hyperinsulinemic, stepped hypoglycemic clamp experiments in healthy volunteers. J Clin Endocrinol Metab 2002, 87:1239-1246.

72. Meier JJ, Kemmeries G, Holst JJ, Nauck MA: Erythromycin antagonizes the deceleration of gastric emptying by glucagon-like peptide 1 and unmasks its insulinotropic effect in healthy subjects. Diabetes 2005, 54:2212-2218.

73. Tolessa T, Gutniak M, Holst JJ, Efendic S, Hellstrom PM: Inhibitory effect of glucagon-like peptide-1 on small bowel motility. Fasting but not fed motility inhibited via nitric oxide independently of insulin and somatostatin. J Clin Invest 1998, 102:764-774.

74. Hellstrom PM, Naslund E, Edholm T, Schmidt PT, Kristensen J, Theodorsson E, Holst JJ, Efendic S: GLP-1 suppresses gastrointestinal motility and inhibits the migrating motor complex in healthy subjects and patients with irritable bowel syndrome. Neurogastroenterol Motil 2008, 20:649-659.

75. Nikolaidis LA, Elahi D, Hentosz T, Doverspike A, Huerbin R, Zourelias L, Stolarski C, Shen YT, Shannon RP: Recombinant glucagon-like peptide-1 increases myocardial glucose uptake and improves left ventricular performance in conscious dogs with pacing-induced dilated cardiomyopathy. Circulation 2004, 110:955-961

76. Sokos GG, Nikolaidis LA, Mankad S, Elahi D, Shannon RP: Glucagon-like peptide-1 infusion improves left ventricular ejection fraction and functional status in patients with chronic heart failure. J Card Fail 2006, 12:694-699.

77. Nauck MA, Walberg J, Vethacke A, El-Ouaghlidi A, Senkal M, Holst JJ, Gallwitz B, Schmidt WE, Schmiegel W: Blood glucose control in healthy subject and patients receiving intravenous glucose infusion or total parenteral nutrition using glucagon-like peptide 1. Regul Pept 2004, 118:89-97.

78. Meier JJ, Weyhe D, Michaely M, Senkal M, Zumtobel V, Nauck MA, Holst JJ, Schmidt WE, Gallwitz B: Intravenous glucagon-like peptide 1 normalizes blood glucose after major surgery in patients with type 2 diabetes. Crit Care Med 2004, 32:848-851.

79. Sokos GG, Bolukoglu H, German J, Hentosz T, Magovern GJ, J., Maher TD, Dean DA, Bailey SH, Marrone G, Benckart DH, Elahi D, Shannon RP: Effect of glucagon-like peptide-1 (GLP-1) on glycemic control and left ventricular function in patients undergoing coronary artery bypass grafting. Am $J$ Cardiol 2007, 100:824-829.

80. Mussig K, Oncu A, Lindauer P, Heininger A, Aebert H, Unertl K, Ziemer G, Haring HU, Holst JJ, Gallwitz B: Effects of intravenous glucagon-like peptide-1 on glucose control and hemodynamics after coronary artery bypass surgery in patients with type 2 diabetes. Am J Cardiol 2008, 102:646-647.

81. Deane AM, Chapman MJ, Fraser RJ, Burgstad C, Besanko LK, Horowitz M:The effect of exogenous glucagon-like peptide- 1 on the glycaemic response to small intestinal nutrient in the critically ill: a randomised double-blind placebo controlled cross over study. Crit Care 2009, 13:R67.

82. Deane AM, Chapman MJ, Fraser RJ, Summers MJ, Zaknic AV, Storey JP, Jones KL, Rayner CK, Horowitz M: Effects of exogenous glucagon-like peptide-1 on gastric emptying and glucose absorption in the critically ill: relationship to glycemia. Crit Care Med 2010, 38:1261-1269.

83. Theodorakis MJ, Carlson O, Michopoulos S, Doyle ME, Juhaszova M, Petraki K, Egan JM: Human duodenal enteroendocrine cells: source of both incretin peptides, GLP-1 and GIP. Am J Physio/ 2006, 290:E550-E559.

84. Dupre J, Ross SA, Watson D, Brown JC: Stimulation of insulin secretion by gastric inhibitory polypeptide in man. J Clin Endocrinol Metab 1973, 37:826-828.

85. Meier JJ, Nauck MA, Schmidt WE, Gallwitz B: Gastric inhibitory polypeptide: the neglected incretin revisited. Regul Pept 2002, 107:1-13.

86. Layon AJ, Florete OG, Jr, Day AL, Kilroy RA, James PB, McGuigan JE: The effect of duodenojejunal alimentation on gastric $\mathrm{pH}$ and hormones in intensive care unit patients. Chest 1991, 99:695-702.

87. Xiao Q, Boushey RP, Drucker DJ, Brubaker PL: Secretion of the intestinotropic hormone glucagon-like peptide 2 is differentially regulated by nutrients in humans. Gastroenterology 1999, 117:99-105.

88. Dube PE, Brubaker PL: Frontiers in glucagon-like peptide-2: multiple actions, multiple mediators. Am J Physiol 2007, 293:E460-E465.

89. Meier JJ, Nauck MA, Pott A, Heinze K, Goetze O, Bulut K, Schmidt WE, Gallwitz B, Holst JJ: Glucagon-like peptide 2 stimulates glucagon secretion, enhances lipid absorption, and inhibits gastric acid secretion in humans. Gastroenterology 2006, 130:44-54

90. Tsai CH, Hill M, Asa SL, Brubaker PL, Drucker DJ: Intestinal growth-promoting properties of glucagon-like peptide-2 in mice. Am J Physiol 1997, 273(1 Pt 1):E77-E84

91. Burrin DG, Stoll B, Jiang R, Petersen Y, Elnif J, Buddington RK, Schmidt M, Holst JJ, Hartmann B, Sangild PT: GLP-2 stimulates intestinal growth in premature TPN-fed pigs by suppressing proteolysis and apoptosis. Am J Physiol Gastrointest Liver Physiol 2000, 279:G1249-G1256.

92. Jeppesen PB, Hartmann B, Thulesen J, Graff J, Lohmann J, Hansen BS, Tofteng F, Poulsen SS, Madsen JL, Holst JJ, Mortensen PB: Glucagon-like peptide 2 improves nutrient absorption and nutritional status in short-bowel patients with no colon. Gastroenterology 2001, 120:806-815.

93. Jeppesen PB, Sanguinetti EL, Buchman A, Howard L, Scolapio JS, Ziegler TR, Gregory J, Tappenden KA, Holst J, Mortensen PB: Teduglutide (ALX-0600), a dipeptidyl peptidase IV resistant glucagon-like peptide 2 analogue, improves intestinal function in short bowel syndrome patients. Gut 2005, 54:1224-1231.

94. Niederau C, Grendell JH: Role of cholecystokinin in the development and progression of acute pancreatitis and the potential of therapeutic application of cholecystokinin receptor antagonists. Digestion 1999, 60(Suppl 1):69-74

95. Shiratori K, Takeuchi T, Satake K, Matsuno S: Clinical evaluation of oral administration of a cholecystokinin-A receptor antagonist (loxiglumide) to patients with acute, painful attacks of chronic pancreatitis: a multicenter dose-response study in Japan. Pancreas 2002, 25:e1-e5.

96. Takala J, Ruokonen E, Webster NR, Nielsen MS, Zandstra DF, Vundelinckx G, Hinds CJ: Increased mortality associated with growth hormone treatment in critically ill adults. N Engl J Med 1999, 341:785-792.

97. Doig GS, Simpson F, Finfer S, Delaney A, Davies AR, Mitchell I, Dobb G: Effect of evidence-based feeding guidelines on mortality of critically ill adults: a cluster randomized controlled trial. JAMA 2008, 300:2731-2741.

98. Zander M, Madsbad S, Madsen JL, Holst JJ: Effect of 6-week course of glucagon-like peptide 1 on glycaemic control, insulin sensitivity, and betacell function in type 2 diabetes: a parallel-group study. Lancet 2002, 359:824-830

99. Mecott GA, Herndon DN, Kulp GA, Brooks N, Al-Mousawi AM, Kraft R, Rivero HG, Williams FN, Branski LK, Jeschke MG: The use of exenatide in severely burned pediatric patients. Critical Care 2010, 14:R153.

100. Meier JJ, Hucking K, Holst JJ, Deacon CF, Schmiegel WH, Nauck MA: Reduced insulinotropic effect of gastric inhibitory polypeptide in first-degree relatives of patients with type 2 diabetes. Diabetes 2001, 50:2497-2504

101. Kouris GJ, Liu Q, Rossi H, Djuricin G, Gattuso P, Nathan C, Weinstein RA, Prinz RA: The effect of glucagon-like peptide 2 on intestinal permeability and bacterial translocation in acute necrotizing pancreatitis. Am J Surg 2001 181:571-575.

102. Besselink MG, van Santvoort HC, Buskens E, Boermeester MA, van Goor H, Timmerman HM, Nieuwenhuijs VB, Bollen TL, van Ramshorst B, Witteman BJ, Rosman C, Ploeg RJ, Brink MA, Schaapherder AF, Dejong CH, Wahab PJ, van Laarhoven CJ, van der Harst E, van Eijck CH, Cuesta MA, Akkermans LM, Gooszen HG: Probiotic prophylaxis in predicted severe acute pancreatitis: a randomised, double-blind, placebo-controlled trial. Lancet 2008, 371:651-659.

doi:10.1186/cc9039

Cite this article as: Deane A, et al:: Bench-to-bedside review: The gut as an endocrine organ in the critically ill. Critical Care 2010, 14:228. 